\title{
Study on the Spatial Pattern of Academies in Jiangxi, China
}

\author{
Yuhan Dong, Xiaofeng Li and Yuan Gao \\ Huazhong University of Science and Technology, China
}

\begin{abstract}
The academy is a type of building which combines the function of academic communication and ritual worship in ancient China. The construction of academies in Jiangxi Province which is in the Yangtze River valley in the South Area of China was among the forefront in Chinese history. The academies are of complete architectural form and well preserved.This paper focuses on the analysis of the spatial pattern of academies in Jiangxi Province, discusses the space construction method, and finds out the essence of the space construction in order to provide the basis and reference for the follow-up study.
\end{abstract}

Keywords: Academies, Jiangxi Province, Spatial Pattern, Space Creation

\section{Introduction}

The name "academy" first appeared in Lizheng Academy in Tang Dynasty. At that time, although there were certain teaching activities in the academy, the main function was only book collection. In other words, the academies at that time were not typical. The academies which acted as schools developed in the middle of Tang Dynasty. During this period, the political situation was chaotic, the official school decayed, and the scholars lived in seclusion. Moreover, influenced by Buddhist preaching, the private reading places gradually became places for lectures. This time the earliest academies such as Guiyan Academy and Dongjia Academy were constructed in Jiangxi Province. At the times of Five Dynasties, there were frequent changes of regime and instability in the political situation, but the South Area in China was in peace. As a result, the academies went on further development. At the same time, a number of education regulations formed and the number of academies constructed in Jiangxi Province ranked first in China. During the Song Dynasty, the academies in Jiangxi Province reached the hey day of history. In the Northern Song Dynasty, the government valued the imperial examination a lot and the official schools were not thriving, which greatly promoted the development of academies. During that time, the academies cultivated large numbers of intellectuals, especially in Jiangxi Province. In the Southern Song Dynasty, due to the decline of official schools and the corruption of imperial examination, coupled with the spread of neo-Confucianism and Lu Jiuyuan's Theory of the Mind, folk lecture activities flourished and the regulations of the academy gradually became complete. The encouraging attitude of the Yuan Dynasty rulers and the continuing spread of the Neo Confucianism promoted the development of the academies in Jiangxi Province. Because of the growing intervention by the government, the academies of Yuan Dynasty became official schools. At the beginning of the Ming Dynasty, the government once banned the academies four times. As a result, the academies in Jiangxi Province suffered a great depression. As Wang Yangming inherited Lu Jiuyuan's Theory of the Mind, the academies in Jiangxi Province once again flourished. However, at the end of the Ming Dynasty, due to the decline of the Theory of the Mind, the academy gradually became a vassal of the imperial examination. At the beginning of the Qing Dynasty, the academy adopted the policy of restraining, until the middle of the term to support it. The officialization of the academy in Jiangxi Province reached its zenith and became an education institution for the imperial examination completely. At this time, although the number of academies has increased significantly, but its overall development trend is declining. In the modern times, the original mode of education no longer adapted to the development of the 
society. As a result, many academies in China transformed into new schools, Jiangxi Province was of no exception. All in all, this is the end of the history of the academies in Jiangxi Province (TABLE I).

TABLE I: Number of Academies in Jiangxi Province throughout the Ages

\begin{tabular}{|l|l|l|l|l|l|l|}
\hline Tang & Five Dynasties & Northern Song & Southern Song & Yuan & Ming & Qing \\
\hline 7 & 6 & 39 & 123 & 94 & 287 & 323 \\
\hline
\end{tabular}

\section{The Location and Spatial Pattern of Academies in Jiangxi Province}

\subsection{Location}

The academy got the advantages of both official and private schools, so it became a unique educational institution in ancient times. As it played an important role in education, the founders of the academy thought highly of the location. As time went by, the view of location with regional characteristic finally formed.

The location of academies in Jiangxi Province can be divided into four types. The first type is surrounded by mountains, the second is fronting water and with mountains on the back, the third is surrounded by water and the last is in the marketplace. The first three types are commonly seen (TABLE II). It can be seen that most academies in Jiangxi Province are located in the beautiful natural environment. Although some folk academies are built in the marketplace, plants, rockeries and other elements are brought into the academies to compensate for the lack of natural environment.

TABLE II: Location Types of Academies in Jiangxi Province

\begin{tabular}{|c|c|c|c|}
\hline $\begin{array}{c}\text { Surrounded by } \\
\text { mountains }\end{array}$ & $\begin{array}{c}\text { Fronting water and with } \\
\text { mountains on the back }\end{array}$ & Surrounded by water & In the marketplace \\
\hline & & & \\
\hline
\end{tabular}

The reasons why the academies in Jiangxi Province are located in the natural environment with beautiful scenery are as follows:

\subsubsection{Topographical Condition and the Need for Teaching}

The north part of Jiangxi Province is relatively flat, but the south, east and west parts are surrounded by mountains.Meanwhile, the landforms of the central part are mainly hills and mountains. Based on the complex terrain conditions, the academies in Jiangxi Province are adapted to local conditions. As a result, the sites are located in the beautiful natural environment. From the perspective of the educational function of the academy, the scenic areas are far from the worldly bustle, which provide an excellent study environment. Thus, the character of the people in the academy is cultivated in the natural environment and the aim of enlightenment is achieved.

\subsubsection{Influence of Buddhism, Taoism and Confucianism}

The academy was influenced by the Buddhist monasteries since it was first formed. During the Wei and Jin Dynasty, Buddhist monks built temples in scenic areas to preach Buddhism. Thus, the view of choosing resort place for the temple site also had a great influence on the academy. The core value of Taoism is the belief of the gods. The fairyland where the gods live has a nice natural scenery which influenced the academy's view of location as well.

Neo Confucianism which was popular in Jiangxi Province regarded Confucian ethics as the core theory. It absorbed the Buddhism and Taoism in cosmology and speculative theory, focusing on the relationship between the universe and human's behavior. The Confucian values, aesthetic taste, life ideal and other concepts were involved into the establishment of the academy to obtain the otherworldly spiritual pursuit.All in all, the transcendence of Confucian humanistic spirit has a profound influence on the location of the academies in Jiangxi Province. 


\subsubsection{The Product of Feng Shui Culture}

The concept of Feng Shui is an important basis for site selection in ancient China. As a kind of important educational building, the academy is also influenced by Feng Shui Culture. Many records of academies have illustrated the site selection of the academies. From the perspective of Feng Shui, wood is good for education and water can nourish the wood, so there should be plants and water in the site of the academy. The theory of Feng Shui also has a scientific basis. The mountains around the site prevent the invasion of winter wind and the river near the site can provide water for living and agriculture. In addition, in order to follow the position of Wenquxing who is in charge of education and examination, the academies are mostly built in the southeast of the city. It can be seen that the site selection of academies in Jiangxi Province is based on the Feng Shui Culture.

\subsection{Spatial Pattern}

Based on its own function, geographical environment, history and culture, the academies in Jiangxi Province form a diversified spatial pattern. Its type can be summarized as the following three kinds :

\subsubsection{Axis of Symmetry}

In addition to the pursuit of otherworldly realm of spirit, the academies also reflect the humanistic spirit of the secular.Confucianism has always been closely linked with the political order of the secular society, which also reflects the pattern of architectural space. Some academies in Jiangxi Province, especially official academies, mainly take the layout form of axial symmetry and the combination of courtyard. Lecture hall, library, worship building are respectively arranged on a central axis by grade and other ancillary buildings are symmetrically distributed on both sides of the axial line, which fully reflects the strict order of the feudal ethics and civilities. Taking Ehu Academy as an example, on the central axis, the screen wall, gate, torii, Pan Chi (pool in front of the academy) and champion Bridge, secondary gate, lecture hall and library are arranged in turn. The dormitories are distributed on both sides of the central axis. There are totally five courtyards in the entire space sequence. The library is at the end of the central axis, its east is Guan Yu Temple, with Wenchang Pavilion(pavilion for Wenquxing) on the west. This kind of layout brings out the status of the library and perfectly exerts the Confucian etiquette ideology(Fig. 1 Fig. 2).

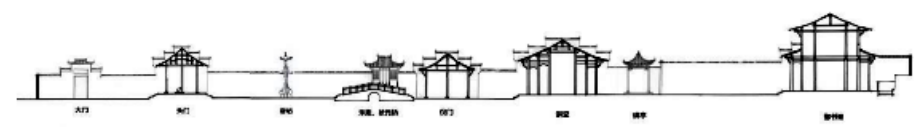

Fig. 1: The space sequence of Ehu Academy

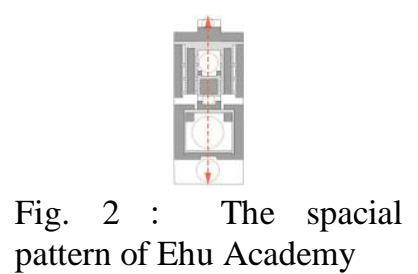

pattern of Ehu Academy

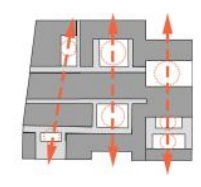

Fig. 3 : The spacial pattern of Yangshan Academy

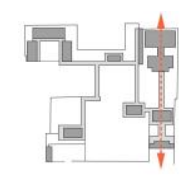

Fig. 4 : The spacial pattern of Dieshan Academy

\subsubsection{Multi Axis Parallel}

Because of the terrain conditions, the academies in Jiangxi Province mostly adopted the spatial layout of multi axis parallel and develop towards horizontal direction. Teaching, library, worship, living area and other buildings of different functions are all in their respective axis and form courtyards. From the direction of width, the axises are combined together. For example, Yangshan Academy takes the lecture hall as the main axis. Worship, library and living area form respective axis on both sides of the main axis and form the the spatial pattern of three axis parallel(Fig. 3) . 


\subsubsection{Free Layout}

This type of academies were mostly built by folk organizations, so they are less influenced by the government. What is more, due to the limitation of the complex terrain conditions, the layouts of many academies are closely combined with topography, which is more flexible. The space atmosphere is similar to the traditional Chinese garden. But the layout of important buildings is still axisymmetric, which shows the profound influence of Confucianism. For instance, Dieshan Academy put important buildings ritual gate, Wenchang Pavilion and Minglun Hall on one axis. Other buildings are arranged according to the terrain condition, which form a vivid and well-proportioned spatial pattern(Fig. 4).

\section{The Main Function of Academies in Jiangxi Province}

\subsection{Teaching}

Teaching is the most important function of the academy and it plays an important role in social education. Teaching can be divided into three types. The first one is the principle taught the students by spreading academic thoughts and answering questions, which was the main way of teaching in the academy. The second one is open lectures towards the society in order to expand the influence of the academy. The third one is lectures with the purpose of academic exchange and discussion. In the Southern Song Dynasty, Theory of the Mind and Neo Confucianism both reached a top level, Zhu Xi and the Lu brothers once had a heated debate in Ehu Academy.

\subsection{Worship}

Worship is another kind of education in addition to teaching. Students could learn from the ancient sages through ritual activities. In this way, the goal of educating people was achieved.The worshipped object not only included Confucius and Mencius, but also representative figures of the academy and people who had made outstanding contributions to the academy. Moreover, gods in charge of examinations such as Wenquxing and Kuixing were also worshipped object.

\subsection{Library}

The function of library formed since Tang Dynasty, its history is even more longer than the function of teaching. The function of library served the daily life of teachers and students, and plays the role of cultural communication. Since the collection of books is the guarantee of the status and enrollment, many academies built independent library. Some large official academies even had royal libraries rewarded by the Emperor. In addition to the function of book collection, the royal library also has the function of book engraving and printing. Due to the small amount of book collection, a few folk academies did not set up independent building for collecting books.

\subsection{Living}

In addition to teaching, the academies in Jiangxi Province also provides dormitories for reading and resting. Though living is only a subsidiary function of the academy, teachers and students spent most of the time in the dormitory, which had great significance. Thus, living is also one of the most important functions of academies in Jiangxi Province.

\section{Analysis on the Space of Academies in Jiangxi Province}

The space construction of the academies in Jiangxi Province is in a distinctive characteristic. It also pays attention to the creation of the space atmosphere, while meeting the basic needs of use, which fully reflects the educational philosophy and academic culture of the academy. There are some common characteristics in the space, which will be explained from five parts: entrance space, teaching space, worship space, library collection space and living space. 


\subsection{Entrance Space}

The entrance of the academies in Jiangxi Province is usually enclosed by walls to form courtyards. The gate is at the side wall and highly above with the form of torii. The roof is mainly hip roof or Gablet roof. A board of the name of the academy is at the head of the gate, which establishes a strong academic atmosphere and acts as a guide to the entrance space sequence. After the gate is the courtyard with a large scale. Trees are planted in the yard to create a quiet atmosphere. In this way, the hustle and bustle can be isolated from the outside walls and the courtyard plays the role of buffer transition, which fully expresses the pursuit of otherworldly Confucian humanism. There are no other buildings in the courtyard, so people can be introduced into the main building easily (Fig. 5). A few academies do not set the space of the courtyard and isolate the outside world by the gate of the main building(TABLE III).

TABLE III: Location types of academies in Jiangxi Province

\begin{tabular}{|c|c|c|}
\hline Entrance type & Entrance with courtyard & Entrance without courtyard \\
\hline Graphic & Ehu Academy & Yangshan Academy \\
\hline Typical & & \\
\hline
\end{tabular}

Fig. 5: The entrance space of Ehu Academy

\subsection{Teaching Space}

The core building of the teaching space is the lecture hall. Due to the importance of the teaching function, the lecture hall is usually located in the center of the academy (TABLE IV). The entire teaching space consists of the lecture hall and the courtyard. There are three types of the enclosure of the courtyard. The first one is the gate, courtyard wall and the lecture hall enclose a courtyard. There are doors to enter other courtyards, so the space is full of permeability, such as Lianjiang Academy. The second type of enclosure is the gate, wing-room and the lecture hall form an isolated courtyard. The space is quiet and cozy, so a good environment of teaching is created, such as Yangshan Academy. The courtyard of the third type is of a large scale. The courtyard is usually divided into two parts by a gate. The courtyard near the lecture hall is small so that the teaching activity is not disturbed by the outside. Another courtyard is large, torii, Pan Chi and champion Bridge are often set up to flatter the sacred status of the lecture hall, such as Ehu Academy. As to the academy of free layout, the lecture hall is arranged according to local conditions, but the creation of the atmosphere is also highly regarded. As a result, the lecture hall is often located in the center or at the end of the axis,a courtyard is also created, such as Dieshan Academy. 
TABLE IV: The Teaching Space Type of Academies in Jiangxi Province

\begin{tabular}{|c|c|c|c|c|}
\hline $\begin{array}{l}\text { The location of } \\
\text { the lecture hall } \\
\text { and courtyards }\end{array}$ & {$[B$} & W & 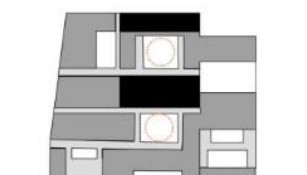 & 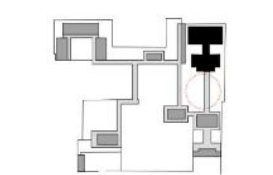 \\
\hline Photos & & & & \\
\hline $\begin{array}{l}\text { Typical } \\
\text { example }\end{array}$ & Ehu Academy & Lianjiang Academy & Yangshan Academy & Dieshan Academy \\
\hline
\end{tabular}

\subsection{Worship Space}

Worship is the most ceremonial activities of academies in Jiangxi Province and plays an important role in education. Students must be led by the teacher to worship the ancient sages before teaching activities in order to use the oracle to encourage students to work hard. Therefore, the worship space attaches great importance to create a solemn ceremony atmosphere.

There are three types of worship space in the academies of Jiangxi Province (TABLE V). The first one is to set up an open courtyard in front of the temple. The courtyard can accommodate more teachers and students to facilitate the large-scale worship activities. Meanwhile, the open space can provide a good view of the elevation. The temple is on a high base, which makes people perceive its large scale and inspires the feeling of worship, such as Dieshan Academy. The second type is to set up a worship pavilion before entering the main worship space and the temple is joined by Kuixing pavilion. Kuixing pavilion and the temple are on a high base and of large scale. What is more, the courtyard before the worship pavilion is small, which gives people a great sense of depression and fear. Thus, a strong atmosphere of worship fills the space, such as Lianjiang Academy. The third type is to arrange the temples at both sides of the axis. The space gets light through the patio and there are no independent courtyards, such as Ehu Academy.

TABLE V: The Worship Space Type of Academies in Jiangxi Province

\begin{tabular}{|c|c|c|c|}
\hline $\begin{array}{c}\text { The location of } \\
\text { the temple }\end{array}$ & \\
\hline Typical example & Dieshan Academy & Lianjiang Academy & Ehu Academy \\
\hline
\end{tabular}

\subsection{Library Collection Space}

The books in academies of Jiangxi Province are the media of cultural communication. The activities of teachers and students are mostly around books. Therefore, library collection is one of the most important functions of the academies in Jiangxi Province and most academies set up space for book collection. The main building of the space is the library, which is usually at the end of the axis. The library space can be divided into two types. The first one is to set the book collection space on the second floor with worship space on the first floor to avoid moisture damage to the books. The second type is to set the book collection space at the side room of the temple, which combines the function of worship and library. There is often a courtyard in front of the library (some libraries set up backyards). The courtyard uses trees to decorate without other ornaments. In this way, a quiet atmosphere is created and the cultural characteristics of the library are brought out. In addition, the academies of free layout arrange libraries according to the local conditions (TABLE VI). 
TABLE VI: The Library Collection Space Type of Academies In Jiangxi Province

\begin{tabular}{|l|c|c|c|c|}
\hline $\begin{array}{c}\text { Types of } \\
\text { library } \\
\text { collection } \\
\text { space }\end{array}$ & $\begin{array}{c}\text { At the end of the } \\
\text { axis, with courtyard } \\
\text { and backyards. }\end{array}$ & $\begin{array}{c}\text { At the end of the } \\
\text { axis, with courtyard } \\
\text { in front. }\end{array}$ & $\begin{array}{c}\text { At the end of the } \\
\text { axis,with book collection } \\
\text { space at the side room of } \\
\text { the temple. }\end{array}$ & $\begin{array}{c}\text { Arranged according to the local } \\
\text { conditions. }\end{array}$ \\
\hline Graphic & Ehu Academy & Yangshan Academy & Lianjiang Academy & Dieshan Academy \\
\hline $\begin{array}{l}\text { Typical } \\
\text { example }\end{array}$ & &
\end{tabular}

\subsection{Living Space}

The dormitory is the place where teachers and students mainly lived. The dormitories of academies in Jiangxi Province are at both sides of the axis or at the corner. The dormitories enclose courtyard with walls or other rows of dormitories. The courtyards are quite small, flowers and trees are planted in the yards. The space is of high privacy and provides a quiet place for reading. The area of the academy is related to the size of the academy and the number of students. The layout is compact and can only accommodate the basic furniture, such as chairs and beds. Besides, academies of free layout arrange dormitories according to the local conditions, but the core space is still courtyard (TABLE VII).

TABLE VII: The Living Space Type Of Academies In Jiangxi Province

\begin{tabular}{|c|c|c|c|}
\hline Types of living space & At both sides of the axis & At the corner & $\begin{array}{c}\text { Arranged according to the local } \\
\text { conditions }\end{array}$ \\
\hline Graphic & & \\
\hline Typical example & Ehu Academy & Yangshan Academy & Dieshan Academy \\
\hline
\end{tabular}

\section{Summary}

The academies of Jiangxi Province is a product of Chinese ancient ritual culture, its development has witnesses the prosperity of neo-Confucianism and Theory of the Mind, which plays an important role in the development of local academy education. The method of space creation and environmental design also has a great significance on contemporary educational architecture design. It can be seen that the academy of Jiangxi Province is a precious architectural heritage. However, with the changes of the times, the academies in Jiangxi Province are greatly damaged. Therefore, the protection and adaptive reuse of the academies is important. Only in this way can we continue to obtain a deeper level of cultural connotation and learn the wisdom of the ancients, the academies of Jiangxi Province will also come back to life.

\section{Acknowledgements}

This paper is supported by the National Natural Science Fund of China, code 51678257.

\section{References}

[1] Liu Xinghua. Research on Formation of the Academy Building in Jiangxi Area [D]. Wuhan:Huazhong University of science and technology, 2013

[2] Pan Fangdong. The Parsing on the Architectural prototype of Hubei \& Hunan Areas Folk Academies in Ming and Qing Dynasy [D]. Wuhan:Huazhong University of science and technology, 2013

[3] Zhu Hanmin, Deng Hongbo, Gao Fengyu. Academes of the Yangtze River Basin[M]. Wuhan: Hubei Education Press, 2004 